\title{
Innovative Marketing and Consumer Behavior: A Systematic Literature Review
}

\author{
Ritika Malik $^{1 *}$ and Ritika Aggarwal ${ }^{2}$ \\ ${ }^{1}$ Assistant Professor, Bharati Vidyapeeth (Deemed to be University) Institute of Management and Research, \\ New Delhi, India; ritikamalik6989@gmail.com \\ ${ }^{2} \mathrm{PhD}$, Research Scholar (Management), Jhabarmal Tibrewala University, Vidyanagari, Churela - 333001, Rajasthan,
}

India

\begin{abstract}
Purpose: The study was done for the purpose of reviewing the existing systematic literature on innovative marketing and how it is impacting behavior of consumer. Also, this study sheds light on trends of innovation in marketing and choice of consumer and their behavior. Methodology: Top peer reviewed published articles were reviewed and study was conducted. A comprehensive strategy for searching database from Google Scholar was applied and journal between 1960-2020 were selected. Findings: Initially the articles on innovation, marketing, consumer behavior were accessed which are published in top marketing journals. Research Limitations: Only top-ranking articles, peer reviewed in ABDC Journal are taken for the study ( $A$ and $A^{*}$ for literature review and $A, A^{*}, B$ and $C$ category from ABDC only for rest of study).
\end{abstract}

Keywords: Consumer Behavior, Innovation, Marketing, Systematic Review of Literature

\section{Introduction}

Innovation is bringing change, carrying new things to an old concept or tradition and marketing is to deliver anything in outside world. The basic function of a business enterprise is to create customers by marketing their innovative products. Innovation gives new idea and then marketing it produce results, all other things are cost (Franklyn. A Manu). The companies with continuous innovation are successful today which are consistently creating new knowledge, with changing markets, developing technology and habits of consumer the company's models needs revision (Olarte-Pascual N. M.-S., 2016). Marketing literature's pervasive topic is innovation. Both disciplines are interlinked because of their overlapping nature. (D. M. Ennis, 1987) the unmet needs of customer make a perception which initiates this process of innovation leading to developing, producing and marketing a new opportunity. Therefore, invention, development of product, commercialization and adaption and upgradation of subsequent product are included in innovation with market research.

Tourism organization's key factor of competition is its innovation capability. With introduction of innovation of product and offering these new services, sales methods that are marketing innovation also needs to change significantly (Diaz-Meneses, 2016). Despite product's extensive development and innovative process, the strategies of novel marketing have gained little attention. With product innovation there are innovations in process of product marketing, new tool of marketing and developed methods are playing major role in industrial revolution (Chen, 2006). However according to (Cavusgil, 2015) there are plentiful evidences of such type of marketing, significant changes like designing of product, its packing (e.g., refill ketchup bottles, QR

${ }^{*}$ Author for correspondence 
codes on interactive packaging, authenticity of products can be checked with invisible watermarks on labels, recyclable packaging), new vistas for promoting various brands and products examples various promotional contests on social media, sharing of reviews of customers, customized advertising using geolocation innovative methods of distributing products (e.g., selling directly, live demonstrations, marketing plans with multilevel networks) and product pricing in new ways (e.g., prepaid, dynamic pricing). According to (Suraksha Gupta, 2013), changing customer needs and market nature there is a need for development of traditional models of business because of highly competitive markets and demanding customers with improved business capabilities and no or very less geographical limitations. Marketing innovation needs to be investigated originating from these novel ways in which designing, pricing, distribution and promotion of products are included.

\section{Literature Review}

According to (Volery, 2020), today marketing concept and innovation have been brought closer increasingly for capturing an innovation that is of specific type which drives marketing practices by strongly developing and commercializing products along its design, brand, process of distribution and promotion and dimension of prices. Change in attributes of product is based on technological modification. (Peter S.H. Leeflang, 2014) marketing innovation and product innovation complement each other. Further boundaries are blurred with digitalization. To reach customers and creating new value marketers are trying to combine various innovations in marketing, including strategies of marketing aligning innovative offering of product, designing to facilitate task accomplishment and increasing aesthetic experiences advertisement with optimal targeting and to capture customer's attention a unique method of pricing so that new relationships can be forged (C. Whan Park, 1990).

According to (Michele O'Dwyer, 2009), the constraints which hinder the SME's marketing function are poor flow of cash, marketing expertise's unavailability, size of business, tactical and strategic problems related to customers, still SMEs are overcoming these challenges and generating these sales by successfully using practices of innovative marketing. According to (Gilmore, 2009) as these SMEs provide jobs to millions, these practices of innovative marketing are fundamentally important. Enhancement of product, for product distribution there should be alternative channels, new markets should be explored, new system of operation are the primary components of innovative marketing. The six elements which make innovative marketing are marketing variables, focus on customers, focus on market, modification, integrated marketing and the unique proposition.

With product innovation there are innovations in process of product marketing. New tool of marketing and developed methods are playing major role in industrial revolution (J. Carson, 1985). There are many forms of marketing innovation that are different in nature. Through programs of innovative marketing information about the consumer can be gathered in new ways and with technologies firms can reach customers in more effective way and transaction costs for customers have been reduced with use of these new strategies of pricing which were not feasible previously according to (Chen, 2006).

According to (Suraksha Gupta, 2013), changing customer needs and market nature there is a need for development of traditional models of business because of highly competitive markets and demanding customers with improved business capabilities and no or very less geographical limitations. (Halpern, 2010) earlier the firms who wanted to expand business globally faced major constraints but now the global markets are changing due to economic changes and customer's purchasing ability are also shifting, growth is becoming need of business, which is pushing firms towards international markets and operate there. The local firms grow as international firms provide them with new opportunities of business. According to (Nargundkar, 2008) marketing innovation can be fostered with collaboration of foreign territories and local firms also customers can be attracted in this emerging economy.

According to (Olarte-Pascual N. M.-s., 2016), the companies with continuous innovation are successful today which are consistently creating new knowledge with changing markets, developing technology and habits of consumer the companies' models needs revision because the companies' model which are used once are not sufficient for longer period. Companies are now forced to carry these activities of innovative marketing because of intense competition to retain customer their needs to be determined to provide them satisfaction 
(Alina R. Eremina, 2020). With new ideas a value chain can transform its aspects completely, new method of product selling is also marketing innovation. A large enterprise implements marketing innovation more likely. The companies which undergo marketing innovation also go for structural changes (Weerwardena, 2003).

Tourism organization's key factor of competition is its innovation capability. With introduction of innovation of product and offering these new services, sales method that is marketing innovation also needs to change significantly. Communication tools are the new innovations of marketing in hotel sector aided by technological advancement with cutting the cost of reservation for clients and for industries too which use to spend large amount while marketing through traditional methods. The values of intangible resources are the main reason of success of a company. For hotel firms to achieve financial performance learning capabilities of employees are of important role, because it is the individual as well as collective knowledge that favors its learning capabilities. Organizational outcomes can also be achieved with enhanced learning capabilities according to to (DiazMeneses, 2016).
According to (Michele O'dwyer, 2009), evolution of marketing in SMEs depend on the enterprise's life-cycle of how they respond to a new product or demands of market, while satisfying requirements of customers while considering the firms manager's behavior and its life-cycle, leaving behind the traditional methods of marketing now businesses focus more on how to personally contact customers, how information about the customer can be collected, what innovation can be added to a product and how a firm can interact with customers. (Gilmore, 2009) An SME can success with innovating knowledge of its people because these individuals can recognize the opportunity to innovate the product. Also, with system integration and flexibility the process of innovation can be enhanced in SME.

According to to (Levitt, 1960), "marketing is the stepchild of most modern corporations". Rare companies are following up systematic Programmes solidly like experimentation of market and innovation. From last decade many changes have been seen in the market like automation of assembly line is a very revolutionary change. With cyberneticists presence everybody is feeling stronger for their marketing needs. Marketing innovation generally comes from new companies that are small.

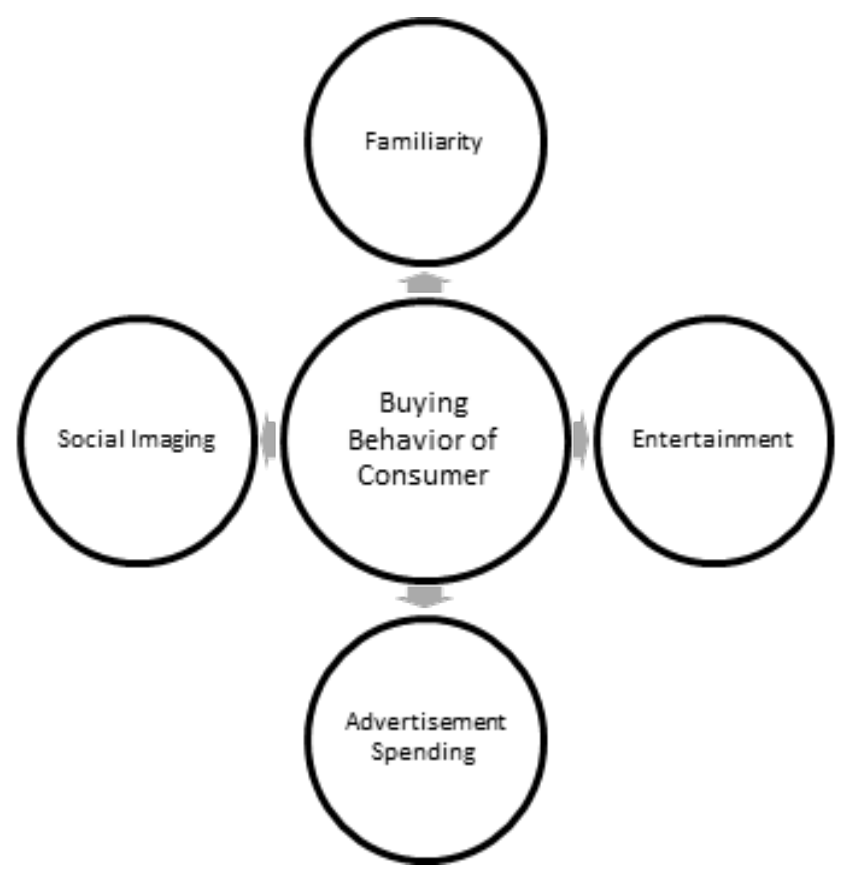

Figure 1. Factors affecting buying behavior of consumer.

Source: Author's own 
According to (Andrew Parsons, 1998) today's modern management is becoming innovation minded leading to organized invention resulting in profit-building. These continuous systematic researches of corporates are giving the output as new products and new methods of production. A company becoming successful in production of new efficient things, needs to think about more creative and imaginative methods of marketing which is very important.

This paper investigates into export innovation's characteristics amongst few firms which recently obtained first order of export. Innovation is adopted in many fields like farmers have adopted new practices of agriculture, new innovative drugs are used by physicians, etc. So, like adopting new process of production entering into market of export is also innovation. Importance of agents who have initiated the innovation has been underlined in the study by (Smith, 1968).

According to (Simmonds, 1986), when an opportunity is identified for change it is viewed as rational innovation in marketing. Through this paradigm direct focus on marketing function can be kept. Innovation is involved in the marketing actions of a firm; these actions are more significant as something is done by the firm for first time. According to (Jessen Floren, 2019) along the several dimensions this innovation concept is basic to function of marketing. Eighth paradigm that is innovation focusses on marketing process as marketing function. According to (Jan-Benedict E.M. Steenkamp, 1992) what marketers are doing that is causing changes in market is viewed in marketing. For marketing, innovation is named as driving force. The fundamental of marketing is change. The task of marketer is identifying, inducing and monitoring innovation.

\section{Research Methodology}

A systematic and thorough review of literature is done to establish and determine research gaps, future expectations of research. Through the method of systematic review of literature, the publications on subject are brought together and evaluated critically as it helps in accessing replicability of the findings and possible inconsistencies if any.

\section{Selection Process}

First, the selection and procedure of search are delineated. Articles on innovative marketing and marketing evolution and behavior of consumer are taken which are published in top peer reviewed journals. For literature review $\mathrm{A}^{*}, \mathrm{~A}$ ranked journals on list of (ABDC) are include. Following journals selected while study are (Economic and Political Weekly, European Journal off Marketing, European Management Journal, International Journal off Contemporary Hospital Management, International Journals of Management, Journals of Air Transport Management, Journal of Business and Industrial Marketing, Journal off Business Research, Journals of Consumers Marketing, Journals of Consumers Research, Journal off Economic and Management Strategy, Global Marketing Journal, Journal off Interactive Marketing, Journal off Management Studies, Journal off Marketing, Journal off Marketing Management, Journal off Strategic Management, Marketing Intelligence and Planning.

Our exclusive focus is on articles published that are in top journals of international marketing which also is a limitation. Time frame has not been considered in the search as articles from 1960 are also examined.

\section{Database Search}

Electronic academic database is consulted from Google Scholar. Innovative marketing, marketing innovation and consumer behavior are used as keywords in the exercise. The keywords used in exercise were searched in titles, abstract of journals and main content. Subsequently, the process of selection was followed. Various research articles were selected for subsequent analysis. In this study no editorials book review was taken for further analysis.

\section{Findings}

Articles on innovative marketing and consumer behavior were searched initially which are published in top marketing journals accessed through google scholar. From Table 1 the process of selection is given by which the articles were searched, what journals were chosen from where they were obtained, keywords use to search the articles, the period from which articles were selected 
Table 1. Selection process

\begin{tabular}{|c|c|c|}
\hline S. No. & Selection Stages & Criteria \\
\hline 1. & Journals Chosen & $\begin{array}{c}\text { ABDC based A* \& A ranked market } \\
\text { innovation and consumers behavior } \\
\text { journal for literature review }\end{array}$ \\
\hline 2. & Search Option & Google Scholar \\
\hline 3. & Keywords & $\begin{array}{c}\text { Marketing, Innovation, Consumer } \\
\text { behavior }\end{array}$ \\
\hline 4. & Period & $\begin{array}{c}\text { Not including editorial, book reviews, } \\
\text { etc. }\end{array}$ \\
\hline 5. & Pre-selected articles & Article title and abstract \\
\hline 6. & Relevance for search & Articles with focus on innovative \\
& Final selection & marketing, consumer behavior \\
\hline
\end{tabular}

Source: Author's own

Table 2. Journals selected

\begin{tabular}{|c|c|c|c|c|c|}
\hline S. No. & Journal & Ranking & Before 2010 & 2010-2020 & Total \\
\hline 1. & Economic and Political weekly & B & 1 & & 1 \\
\hline 2. & $\begin{array}{c}\text { ABDC European Journal off } \\
\text { Marketing }\end{array}$ & $\mathrm{A}^{*}$ & 3 & & 3 \\
\hline 3. & $\begin{array}{c}\text { ABDC European Management } \\
\text { Journal }\end{array}$ & $\mathrm{B}$ & & 1 & 1 \\
\hline 4. & $\begin{array}{c}\text { International Journal off } \\
\text { Contemporary Hospitality } \\
\text { Managements }\end{array}$ & A & & 1 & 1 \\
\hline 5. & $\begin{array}{l}\text { International Journal off } \\
\text { Management ABDC }\end{array}$ & $\mathrm{C}$ & & 1 & 1 \\
\hline 6. & $\begin{array}{c}\text { Journal off Air Transport } \\
\text { Management }\end{array}$ & $\mathrm{B}$ & 1 & & 1 \\
\hline 7. & $\begin{array}{l}\text { Journal of Business and Industrial } \\
\text { Marketing }\end{array}$ & A & & 1 & 1 \\
\hline 8. & Journal off Business Research & A & 1 & & 1 \\
\hline 9. & $\begin{array}{c}\text { ABDC Journal of Consumers } \\
\text { Marketing }\end{array}$ & A & 1 & & 1 \\
\hline 10. & $\begin{array}{c}\text { ABDC Journal of Consumers } \\
\text { Research }\end{array}$ & $A^{*}$ & 1 & & 1 \\
\hline
\end{tabular}




\begin{tabular}{|c|c|c|c|c|c|}
\hline 11. & $\begin{array}{l}\text { Journal off Economic and } \\
\text { Management Strategy }\end{array}$ & A & 1 & & 1 \\
\hline 12. & ABDC Journal of Global Marketing & $\mathrm{B}$ & 1 & & 1 \\
\hline 13. & Journal of Interaction Marketing & $\mathrm{A}$ & 1 & & 1 \\
\hline 14. & ABDC Journal of Management Study & $A^{*}$ & 1 & & 1 \\
\hline 15. & ABDC Journal of Marketing & $\mathrm{A}^{*}$ & 1 & & 1 \\
\hline 16. & Journal of Marketing's Management & A & & 1 & 1 \\
\hline \multirow[t]{2}{*}{17.} & Journal off Strategic Management & A & 1 & & 1 \\
\hline & Total 19 & & & & \\
\hline
\end{tabular}

Source: Author's own

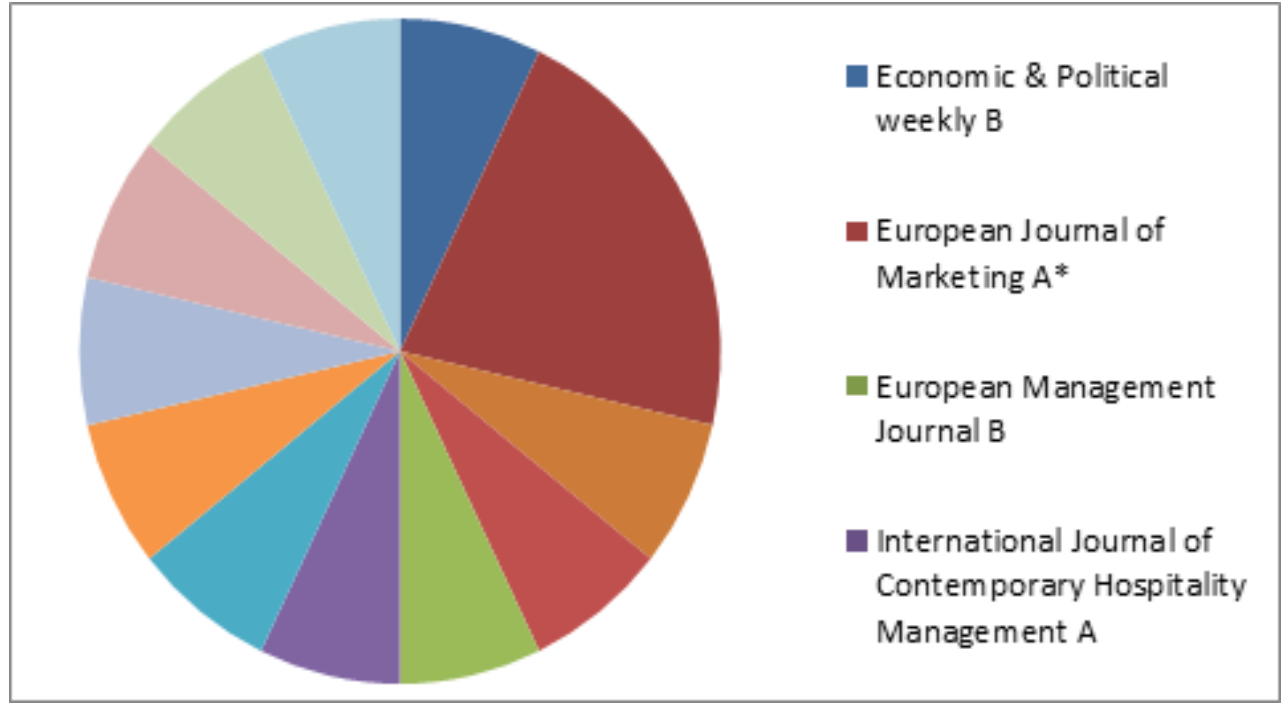

Figure 2. Pie Chart: different journals chosen for study.

Source: Author's own

(1960-2020), editorials were omitted, book reviews were not taken and the relevance and final selection.

In Table 2 the selected journals with their rankings and publication year are mentioned to simplify the study.

\section{Conclusion}

The study's objective was bringing together and systematizing articles of innovative marketing and consumers behavior that are publishing in top journals of international marketing. Marketing innovation impacting the behavior of consumer. Figure 1 shows the different factors like entertainment, social imaging familiarity affecting the buying behavior of consumers. Through the analysis the importance of marketing innovation and its impact on consumer behavior is seen. In Table 1 entire process of selection of articles is given like what kind or ranking journals were selected, for literature review only $\mathrm{A}$ and $\mathrm{A}^{*}$ journals were selected and for the rest of 
study all $A, A^{\star}, B$ and $C$ journals were reviewed that were searched on google scholar. From Table 2 it can be seen that journals which are selected for the study and their time period that is from the starting year (1960) to last year (2020) they are selected. Figure 2 is the pie chart depicting different journals from ABDC selected for the study. With continuous change in customer behavior and their patterns of shopping which is very unpredictable, for brand promotion continuous revolution is becoming essential for marketer. Today customers are actively participating in the entire process of purchase that is what marketing innovation today is focusing upon. For ensuring sustainable growth marketing mix needs to be there that is well designed which also acts as key in marketing competition. Possible impacts of strategies of innovative marketing.

\section{References}

Agarwal V 2010 Innovative marketing practice for evolving consumer Indian Journal off Marketing, 40(8), page 7-12.

Beane T P\& Ennis D. M. (1987) Market .segmentation- a review European journal of, marketing

CarsonD. J. (1985) The evolution off marketing in, small firms. European journal. of marketing.

ChenY. (2006) Marketing innovation. Journal. of Economicsand,Management Strategy, 15(1), page 101-123.

Eremina, A. R Bardadym M. V. Hurtova N. V Zhadko K. S \& Datsenko V,V(2020). Innovative Marketing Tools for Business .Development in the Early Stages of the Crisis. International Journal, of Management, issue 11(5).

Floren J Rasul,. T., Gani, A (2019) Islamic marketing \& consumer behaviour: a systematic, literature review Journal. of Islamic Marketing.

Gilmore A- Innovative marketing in SMEs framework, i-21(6) pg 504-515.

Gupta S, Malhotra N. 2013 Marketing innovation,: a .resource based view of international \& local firms Marketing Intelligence, \& Planning

Halpern N 2010. Marketing innovation.: Sources capabilities \& consequences at, airports in Europe's. peripheral areas. Journal off Air Transport .Management, I 16(2), p 52-58.
Leeflang P.S,Verhoef P C.Dahlströmm P \& Freundt T (2014). Challenges \& solutions for marketing in digital era European management, journal i- 32(1), p-1-12.

Levitt T (1960) Growth \& profit through planned marketing innovation Journal of Marketing 24(4), p-1-8.

Manu F. A, Sriram V (1996) Innovation marketing strategy environment. \& performance. Journal of. business Research, 35(1), p-79-91.

Medrano N \& OlartePascual C(2016) The effects of crisis on marketing innovation an application for Spain.., Journal. of Business, \& Industrial Marketing.

Nieves J \& ,Diaz-Meneses G (2016) Antecedents \& outcomes of .marketing innovation. International, Journal of .Contemporary Hospitality .Management.

OzsomerA. BodurM \& Cavusgil ST 1991. Marketing standardization by multinationals in an emerging market,. European. Journal of Marketing.

ODwyer M. Gilmore A. Carson D. 2009. Innovative marketing in SMEs. an empirical study Journal. of Strategic Marketingi- 17(5), pp-383-396.

Park CW, Smith \& D. C 1990 Product class competitors. as sources of innovative marketing strategies Journal. off Consumer Marketing

Parsons A. Zeiser M. \& .Waitman R 1998 Organizing today, for digital marketing off tomorrow Journal off Interactive Marketing I 12(1)P 31-46

Purchase S \& Volery T. 2020 Marketing innovation a systematic review Journal. of Marketing Management issue 36(9-10) page 763-793

Puri A 2006 Innovative Marketing, Economic. and Political weekly p-3380-3382.

Shergill G. S Nargundkar R 2005Market orientation marketing innovation as performance drivers,, extending paradigm Journal. off Global Marketing issue19(1) page 27-47.

SimmondsK 1986 Marketing. as Innovation- the eighth paradigm Journal of .Management Studies 23(5) 479-500.

SimmondsK SmithH. 1968 The first, export order-a marketing. innovation European Journal off Marketing

Steenkamp J B E. Baumgartner H 1992. The ,role off optimum stimulation.. level in exploratory, consumer behavior Journal off. consumer research 19(3).. 434-448

WeerawardenaJ 2003 The. role off marketing capability,, in innovationbased competitive. Strategy Journal of.. strategic marketing i-11(1) pp 15-35. 